\title{
Christina L. Davis. 2012. Why adjudicate? Enforcing trade rules in the WTO (Princeton: Princeton University Press)
}

\author{
Manfred Elsig
}

Published online: 1 September 2012

(C) Springer Science+Business Media New York 2012

The study of how trade disputes are managed in the global trading system has for a long time been the prerogative of legal scholars and economists. This book by Christina Davis is so far the most comprehensive study by a political scientist on the functioning of the GATT/WTO enforcement system. Following in the footsteps of important contributions by political-legal experts (Hudec 1993) and economists (Bown 2009), Davis has written a fabulous book that will inform and influence the study of dispute settlement in years to come. The book uncovers a wealth of empirical patterns and offers a theory of multilateral trade adjudication rooted in domestic politics and institutional relations between the legislative and executive branches of government. The strength of Why adjudicate is the use of mixed methods to test various explanations as to the drivers and the effects of the GATT/WTO enforcement tools.

In the first part of the book, Davis outlines how governments use international adjudication as a strategic device to signal their commitment to domestic interest groups. From this viewpoint, WTO adjudication "represents a costly signal for the executive to demonstrate commitment to promote market access" (p. 49). She further suggests that the relationship between the legislative and the executive will causally affect the degree to which states will prefer enforcement over negotiations. Legislators value tough enforcement, while the executive branch favors a more cautious approach (including diplomatic bargaining). From this, she derives some implications such as that in countries where the government structure is divided and constraints on the executive are high, we should expect adjudication to be an important enforcement tool (hypothesis 1). Under conditions of high domestic constraints, she also expects that adjudication is used in particular for sending a strong signal to politically influential industries (hypothesis 2). The flip side of this argument is that in cases where legislative and executive bodies are "unified" and constraints on the executive are low in trade policy terms, we should expect more discretion to be given to the executive that privileges negotiations over litigation. Finally, as an extension of her

\footnotetext{
M. Elsig $(\bowtie)$

University of Bern World Trade Institute, Hallerstrasse 6, CH-3012 Bern, Switzerland

e-mail: manfred.elsig@wti.org
} 
argument, Davis posits that "adjudication will be more likely to bring resolution of trade disputes than alternative trade strategies" (p. 57) (hypothesis 3).

Chapters 3-7 provide an empirical assessment of the theoretical arguments put forward. Chapter 3 undertakes a statistical analysis of WTO/GATT cases from 1975 to 2004. This shows that not only are democracies more likely to use legal means of dispute settlement than other regime types, but, as predicted, that "states with high checks and balances at home are the most frequent users of adjudication" (p. 21). While the argument is mainly tested for the likelihood of states filing complaints in Geneva, evidence is also presented that the dynamics for states that find themselves acting as defendants in legal disputes are similar. The less autonomy the executive has, the more it will allow disputes to escalate to show its willingness to defend the industries concerned. Chapter 4 studies in greater detail the so-called litigious state (the US) and in particular tests hypothesis 2 by showing that "political contributions increase the likelihood of a particular case being chosen for a WTO complaint" (p. 103). Given that Davis relies on data that captures the amount of "potential cases" that can be escalated to the WTO dispute settlement system, she is able to control for an important selection bias, a concern that has long challenged the findings of large-n studies conducted to explain the initiation of legal disputes under GATT/WTO. After providing an additional qualitative test of her predictions focusing on the US, she turns in chapter 5 to another WTO member which can be characterized as "the reluctant litigant" (Japan). In this chapter, again using a mixed methods design, she uncovers the factors that reduce the likelihood of using adjudication for dispute settlement. She shows that the priorities of the executive, economic stakes and diplomatic relations drive the behavior that favors negotiations over litigation.

Chapters 6 and 7 assess the impact of using adjudication (in comparison to negotiation) as an enforcement tool to address WTO-inconsistent policies. Chapter 6 shows that, in the case of the US, the political demand for litigation will "filter hard cases into the adjudication forum" (p. 245). Further, using event history models, Davis shows that filing cases will significantly reduce the duration of a dispute. Finally, chapter 7 presents a case study using a controlled comparison design to assess whether developing countries can also use litigation against the US or the EU as an efficient means to address import barriers to a key market. Evidence shows that a WTO member (Peru) could strategically use dispute resolution to change EU labeling policies with regard to fish imports. Vietnam, however, at the time of the study not yet a member of the WTO, had to rely on negotiations and was not able to change US fish labeling policies. The findings suggest that the legal forum is more effective than negotiations.

Overall the book conveys a message that dispute settlement is an efficient tool for managing inter-state relations as well as for pleasing important constituencies at home. This is good news for an organization that is currently experiencing existential crises in terms of rule-making. While the book is an important step forward in the study of GATT/ WTO dispute settlement, it is not without limitations. Let me mention four.

First, Davis does not explicitly address the question why GATT contracting parties experimented with different enforcement mechanisms over time. More importantly she does not explain why they decided to completely change the system in 1995 to create a dispute settlement system characterized by the right to a panel, the quasi automatic bindingness or rulings and the creation of a standing body that is much more independent than the expert panels used in the first stage of dispute settlement (the Appellate 
Body) (Bernauer et al. 2012). When the theoretical interest is in understanding why states use adjudication, the analysis might benefit from a more in-depth discussion of the motives for creating the WTO's "jewel in the crown" in the first place.

Second, and following from the above, given that GATT dispute settlement and WTO dispute settlement differ substantially, it would have been interesting to separate the empirical tests for the GATT period from those for the WTO period more clearly. In my reading, the theoretical argument was specifically developed with the WTO period in mind rather than the old days of diplomatic-political dispute management among a small group of countries. It is also noteworthy that the model estimating dispute initiation does not test the impact of checks on the executive for the WTO period (table 3.3, model 4, p. 82). Further, the model using a dyadic set-up to estimate disputes shows that, for the WTO period, retaliation capacity is an important variable. This calls for more elaboration.

Third, the time period for the analysis ends in 2004. This invites the reader to ask whether extending the period up to 2010 would yield the same or potentially different results. It is fair to assume that by adding six more years of adjudication activity and by focusing more exclusively on the WTO period, the empirical test would turn out to be much stronger. This would also control for more recent structural changes, such as China's accession to the WTO in 2001 or the continuing deadlock in trade negotiations. The latter might have led to increasing incentives for states to using adjudication (and legal rule-making) as an alternative way to make progress in trade liberalization.

Fourth, the theoretical analysis is somewhat US-centric. In this respect, I wonder how many states' executives face similar oversight from the legislative branch, which is very characteristic of the US trade policy system. Further, in the quantitative assessment, the proxies used to test legislative oversight (the World Bank's Database of Political Institutions) might raise some concerns about measurement validity. Do the data on checks sufficiently capture the decisive relationship between the legislative and the executive bodies?

Notwithstanding these limitations, Why Adjudicate is a must-read for any scholar interested in legalization of world politics, the role of international courts and the mechanisms of trade policy. I am sure this book will inspire these research programs and the field of International Political Economy for years to come.

\section{References}

Bernauer, T., Elsig, M., \& Pauwelyn, J. (2012). Dispute Settlement Mechanism-Analysis and Problems. In A. Narlikar, M. Daunton, \& R. M. Stern (Eds.), Oxford handbook on the WTO. Oxford: Oxford University Press.

Bown, C. (2009). Self-enforcing trade: Developing countries and WTO dispute settlement. Washington, DC: Brookings.

Hudec, R. (1993). Enforcing international trade law: The evolution of the modern GATT legal system. Salem: Butterworth. 